\title{
沖縄のコンクリート住宅普及黎明期における仲座久雄の建築活動 ARCHITECTS ACTIVITY ON HISAO NAKAZA IN THE EARLY STAGE OF CONCRETE HOUSE POPULARIZATION IN OKINAWA
}

\author{
金城春野*1, 小倉暢 之*2 \\ Haruno KINJO and Nobuyuki OGURA
}

\begin{abstract}
Hisao Nakaza was one of a handful of architects who contributed to building activities in Okinawa before, during, and after the Second World War. He engaged in the post-war recovery construction in the forefront immediately after the war.

This study defines the period before 1960 as the dawn of concrete house popularization in Okinawa and aims to clarify the aspects of the development of architecture in Okinawa during this period, examining the activity of Hisao Nakaza, who played a leading role in laying the foundation for the spread of concrete buildings.
\end{abstract}

Keywords : Okinawa, Concrete house, Climate, Popularization activity, Hisao Nakaza, Local architect 沖縄, コンクリート住宅, 気候風土, 普及活動, 仲座久雄, 地域建築家

\section{はじめに}

仲座久雄は戦前、戦中、戦後に亘って沖縄で建築活動した数少な い建築家の一人であり注1)、終戦直後から最前線で復興工事に携わり、 その後、沖縄建築士会初代会長を務めた。沖縄建築士会では仲座を 「コンクリートやブロックの新しい材料を取り入れ現代建築を沖縄 に根づかせた最初の建築家」注2) と位置付けており、戦後初期沖縄建 築界の先駆的人物である。1962 年に他界するまで公共施設や住宅を 初め多数の建築を設計したが、その建築活動期間は戦後の建材が乏 しい時期から、鉄筋コンクリート造（以下、 $\mathrm{RC}$ 造）や補強コンクリ ートブロック造（以下、 $\mathrm{CB}$ 造）の施工基盤が整い始めた近代化への 転換期に当たっている注3)。

沖縄県土木部建築課が 1972 年の本土復帰時に作成した建築確認 申請の構造別推移によると、申請件数における非木造が占める割合 は 1957 年まで 1 割台であるが、1961 年に過半に達し、1969 年に は 9 割に昇る注 ${ }^{4)}$ 。これは、1960 年頃を契機に RC 造・CB 造住宅 （以下、コンクリート住宅）が急速に普及したことを表している。 本研究では、1960 年以前をコンクリート住宅普及黎明期と定義 し、当該時期において普及の礎を築くのに重要な役割を果たした人 物の一人である仲座久雄の建築活動を通して、戦後沖縄建築の展開 の一端を解明することを目的とする。

戦後沖縄における $\mathrm{RC}$ 造・ $\mathrm{CB}$ 造建築の普及の過程に関する既往 の研究は複数あり、米軍工事による技術習得や品質改善に係る制度

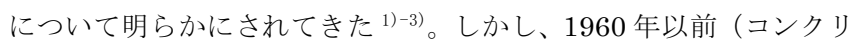
一ト住宅普及黎明期）の戦後沖縄建築を扱った研究は、終戦直後の 木造応急住宅である規格住宅（仲座久雄設計）に関する筆者らによ
る拙稿 ${ }^{4)} 、 1950$ 年に沖縄住宅公社が建設を開始した沖縄初の CB 造 住宅 (以下、公社住宅) に関寸る研究 ${ }^{5) 6)}$ が主なものであり希少であ る。更に、公社住宅は米軍人軍属向けに建設された住宅であり、地 元住民住宅の展開については明らかになっていない部分が多い。 本研究は仲座の遺族から提供を受けた仲座久雄に関する資料 (図面、 写真、手記、新聞記事、辞令) 注5)、沖縄県立博物館による仲座の文 化財保護活動に関する企画展出版物 ${ }^{7)}$ 、及び沖縄建築士会機関紙 ${ }^{8) 9}$ ), 注 6) を基礎資料とし、関係者等の経験談が掲載された出版物 ${ }^{10) 11)}$ 及 び遺族、仲座久雄建築設計事務所元所員への聞き取りにより補足し た。なお、本稿は日本建築学会の研究発表会で報告した拙稿 ${ }^{12)}{ }^{13)}$ まとめ、新たな知見を加えて大幅に加筆したものである。

1 章では、仲座の経歴を整理し携わった建築の時期と特徵を分析 し、建築活動の背景を述べる。2 章では、沖縄建築士会におけるコ ンクリート住宅普及活動に注目し、その内容を考察する。3 章では、 仲座の住宅設計の一覧をもとに、時系列及び構造種別ごとに住宅品 質改善に係る実践内容を分析する。なお、仲座久雄のその他の建築 活動に文化財保護活動注7)があるが、本稿は沖縄建築の近代化の過程 を扱う為、この活動については対象としない。

\section{1. 経歴}

仲座久雄の経歴注 8) を表（Table 1）に示すと、活動拠点や所属を もとに 6 つの期間に大別できる。1)大阪で苦学して建築を学んだ大 阪期、2)帰郷し公共工事に携わった戦前沖縄期、3)終戦後米軍工事 に携わった米軍工事期、4)仲座久雄建築設計事務所を開設した第一 独立期、5)沖縄群島政府建築課長を務めた群島政府期、6)事務所を
*1 琉球大学工学部 助教.工修

*2 琉球大学工学部 教授·学博
Assist. Prof., Faculty of Engineering, University of the Ryukyus, M.Eng.

Prof., Faculty of Engineering, University of the Ryukyus, Ph.D. 
再開し沖縄建築士会会長も務めた第二独立期がある。

本章では、主体的な建築活動が開始された戦前沖縄期以降の 5 つ の期間について 注 ${ }^{9}$ 携わつた主要な建築について特徴を分析し、建築 活動の背景を検討する。

Table 1 Brief personal history

\begin{tabular}{|c|c|c|}
\hline Year & Background & Period \\
\hline 19041 & Born in Nakagusuku village Okinawa & \multirow{6}{*}{ Osaka } \\
\hline 1921 & $\begin{array}{l}\text { Went to Osaka } \\
\text { Joined Toyo boseki (東洋紡績) } \\
\text { Worked and went to Kansai kougakko yoka (関西工学校予科) }\end{array}$ & \\
\hline 1923 & $\begin{array}{l}\text { Entranced into Osakashiritsu kansai kogakko Kenchikugakka } \\
\text { (大阪市立関西工学校建築学科) }\end{array}$ & \\
\hline 19251 & $\begin{array}{l}\text { Entranced into Osakashiritsu Nishitenman shoko senshugakko kogyobu } \\
\text { kenchikugakka (大阪市立西天満商工専修学校工業部建築学科) }\end{array}$ & \\
\hline 1929 & $\begin{array}{l}\text { Entranced into Osakashiritsu Nishitenman shoko senshugakko kogyobu } \\
\text { kenchiku kotoka (大阪市立西天満商工専修学校工業部建築高等科 }\end{array}$ & \\
\hline 1931 & Joined Tanaka gumi (田中組) in Osaka & \\
\hline 19331 & Returned to Okinawa & \multirow{3}{*}{$\begin{array}{l}\text { Prewar } \\
\text { Okinawa }\end{array}$} \\
\hline 1937 & $\begin{array}{l}\text { Okinawa prefecture economy department, civil engineering division, } \\
\text { assistant engineer (沖縄県経済部土木建築課 建築技手補) }\end{array}$ & \\
\hline 1943 & $\begin{array}{l}\text { Assistant engineer of architecture of Okinawa branch of Japan medical } \\
\text { treatment corps (日本医療団神縄県支部建築技師) }\end{array}$ & \\
\hline 1945 & $\begin{array}{l}\text { U.S. naval military government Okinawa public works department } \\
\text { (祌縄海軍軍政府工務部) }\end{array}$ & \multirow{4}{*}{$\begin{array}{l}\text { U.S. military } \\
\text { construction }\end{array}$} \\
\hline 1946 & 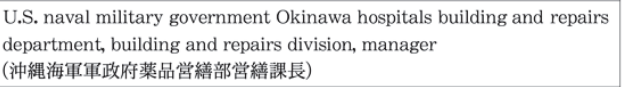 & \\
\hline 1947. & Joined Atkins and Jones (AJ), architectural division, manager & \\
\hline 1948 & Kadena air force, engineering works department (嘉手納航空隊工務部) & \\
\hline 19491 & Established Hisao Nakaza architect office (仲座久雄建筑設計事務所) & 1st independence \\
\hline 1950 & $\begin{array}{l}\text { Okinawa gunto government public works department, architectural } \\
\text { division, manager (蚛縄群島政府工務部建築課長) }\end{array}$ & $\begin{array}{c}\text { Gunto } \\
\text { government }\end{array}$ \\
\hline 19521 & Reopen Hisao Nakaza architect office & \multirow{3}{*}{ 2nd independence } \\
\hline 19551 & $\begin{array}{l}\text { Established Okinawa society of architects \& building engineers, } \\
\text { president (蚛䋲建築士会初代会長) }\end{array}$ & \\
\hline 1962 & Die & \\
\hline
\end{tabular}

\section{1-1. 戦前沖縄期}

大阪に出たのが 1921 年（17 歳）で、帰郷は 12 年後である。帰 郷の年 1933 年には、美里村で落石岩塊災害復旧工事監督員、更に 1934 年には、離島の与那国村小学校校舎災害復旧工事設計及び監督 員を務めており、立て続けに災害復旧工事に関わった注10)。1936 年 に設計した首里市営バス安里駅前車庫は「沖縄では始めての乾式工 事」年)とされ、プレキャストコンクリートを用いたと想定できるが、 当時としては珍しい構法を採用していたことになる。
同年、国宝建造物首里城守礼門修理工事工事主任を務めたが、そ の際に監督として文部省から派遣された森政三注 11) と出会い、これ を契機として仲座の文化財保護活動は本格化し、生涯に亘って続け られた注12)。

1937 年から 1943 年にかけては、沖縄県建築技手として校舎及び ハンセン病療養施設、更に 1943 年末からは、日本医療団沖縄県支 部の建築技師として医療施設の設計建設に複数携わった注 ${ }^{13)}$ 。

戦争が激化した 1944 年、那覇市市街地を襲った十・十空襲（10 月 10 日の大規模な空襲）では自宅を消失したが、被災地の都市計 画に沿った建築指導、本島中南部の住民を山間部の北部へ避難させ る為の疎開小屋の建設に取り組んだ注 ${ }^{14)}$

このように、仲座は戦前から災害復旧工事、校舎や医療施設、疎 開小屋などの建設に携わっており、社会福祉に対する関心の深さが 戦後の復興活動に繋がっていると考えられる。

\section{1-2. 米軍工事期}

終戦直後の 1945 年 11 月 30 日、米国海軍軍政府工務部で規格住 宅 (Photo 1) と呼ばれる 2 インチ×4 インチ角を中心とした規格木 材（ツーバイフォー材）によるプレハブ式応急住宅の設計図を完成 させた。設計を任された経緯には、戦前の疎開小屋建設の経験が影 響していたことが分かっており、地元の事情を知る技術者として米 軍から重宝されたことが窺える。規格住宅は 1946 年から 1949 年 末ごろまでの約 4 年間で 75,000 戸以上が無償供給され、復興に大 いに貢献した注 ${ }^{15)}$ 。

1946 年には、米国海軍軍政府薬品営繕部営縊課長として、病院、 診療所の建設注 ${ }^{16)}$ に関与したが、ここでも戦前の医療施設の経験が 活かされていることが指摘できる。1946 年 9 月に落成した胡差中 央病院は、コンセットと呼ばれる米軍のカマボコ型兵舎注17)を 40 棟 以上設置した大規模な施設であり、既存の屋敷林による区画を活か した配置計画が特徴である注 ${ }^{18)}$ 。

更に翌年には、米軍工事を当時一括して元請していた建設会社 AJ 注 19) に入社、 3 年間建築課長を務めた。この頃について「私はつねづ ね若い人達に対し、技術屋にとって軍作業はアメリカ留学と同じだ よ恵まれたチャンスだよと語ったものであるが、とにかく機械力そ

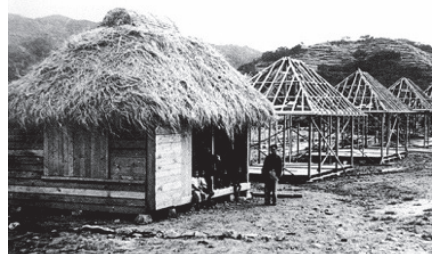

Photo 1 Standard prefabricated house (1946)

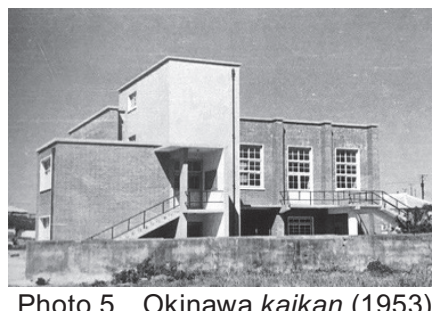

Photo 5 Okinawa kaikan (1953)

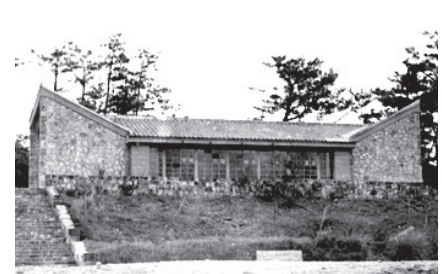

Photo 2 Nakagusuku-jo park store (1949)

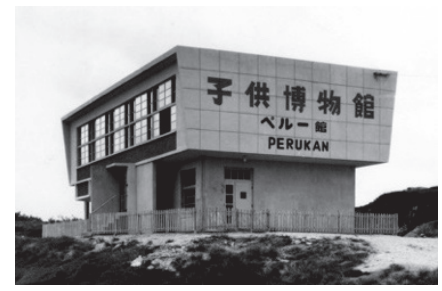

Photo 6 Children's museum (1954)

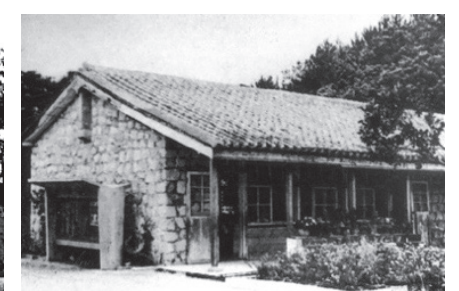

Photo 3 Standard school building (1951)

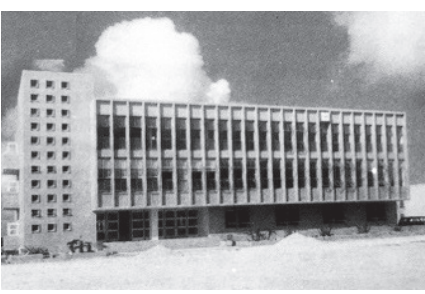

Photo 7 Library of Univ. of the Ryukyus (1955)

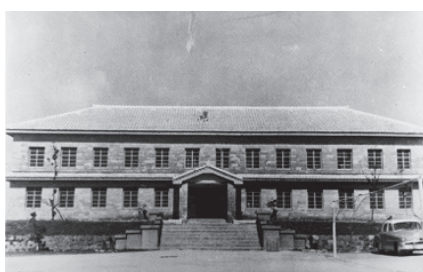

Photo 4 Main building of Univ. of the Ryukyus (1951)

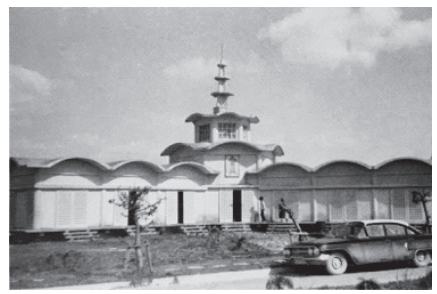

Photo 8 Naha city cinerarium (1957) 
の他学ぶべき事柄が多かった」と振り返っている ${ }^{19)}$ 。

以上のように、仲座は終戦直後から米軍工事に最前線で携わり、 直接的に先進技術を習得していた。また、米軍工事への関与には戦 前の建築経験が影響していたことが指摘でき、地元の事情を知る技 術者として活躍していた様子が窥える。

\section{1 - 3 ． 第一独立期}

1949 年、真和志村松川（現、那覇市松川）に仲座久雄建築設計事 務所を開設、その後事務所を真和志村栄町（現、那覇市大道） 一移 転したが、1950 年 11 月には沖縄群島政府に勤務することになり、 1 年数ヶ月と短期間で事務所を閉鎖した注 ${ }^{20)}$ 。

第一独立期には、中城城公園基本計画を設計した。これは、琉球 王国の時代に築かれた城址とその周辺を範囲とする広大な敷地に、 闘牛場や馬場、野球場などの屋外競技場、売店やダンスホール、料 理店などを含んだ大規模な遊戯施設の計画である注 ${ }^{21}$ 。中城城公園 は、城跡の修繕と整備、馬場や売店などの基本計画の一部の施設を 完成させ、1950 年 3 月に開園した。中城城公園の売店（Photo 2) は、石造の壁と木造赤瓦莫き屋根の形状が特徴であり、必要な壁量 を確保しつつ個性的な外観を形成する工夫が見られる。

また、この時期に設計した住宅 5 件中 3 件は石造や煉瓦造であり (3 章)、1949 年には組積造を採用していたことが分かる。

\section{1 - 4 ． 群島政府期}

1950 年 11 月、沖縄群島政府（以下、群島政府）注 22 ) 発足と同時 に工務部建築課長に就任した。在任中、建築を取り締まる法令がな い中、1951 年 10 月に建築基準条例を制定し（1952 年 1 月施行）、 建築行政を復活させた注 23$)$ 。

群島政府期に設計した代表的な施設に、組積造の標準型校舎注 24) がある。仲座が設計した標準型校舎（Photo 3) は、小石を野面積み した「野石造」、琉球石灰岩の切り石による「栗石造」、瓦工場など で焼成した煉瓦による「煉瓦造」の主に 3 種類ある注25)。これらは、 現地の状況に応じて壁の構造材料選択が可能であり、耐台風と深刻 な木材不足が考慮された、地場材料を活用した非木造建築である。 平屋建て、屋根は木造赤瓦莫き、軒下に廊下が設けられている。構 造の更に大きな特徴として、棟木に替わってプレキャストコンクリ ートのラチス梁が採用されている注 26)。この梁の持ち上げには重機 を用いており、米軍工事による建設機械と操縦技術がある程度普及 していた状況が現れている。このように、標準型校舎は地場材料と 先進技術を融合させた画期的な設計であったといえる。

1951 年 2 月の琉球大学の開学に際し建設された琉球大学本館 (Photo 4) は石造 2 階建て、屋根は木造赤瓦莫きである。首里城正 殿跡に立地し、基壇、入り口の破風、左右対称の構成などに首里城 正殿を意識したことが窥えるが、石造を起因とした空割単位で構成 された比較的簡素な外観である。

このように、群島政府期は組積造を用いており「私は沖縄で多量 にとれる石や煉瓦が使えることを説いて回った」と述べている注27)。 何故なら、沖縄では城跡等で知られる通り、古くから石造文化は存 在するが、家畜小屋や墓などを除いて建築の壁材として扱うことは 珍しく、啓蒙の必要があった。木造建物の相次ぐ台風被害注 ${ }^{28)}$ を背 景に、輸入頼みの木材に替わる地場建材としての石材、煉瓦の実用
性を見出し、建築実践と啓蒙活動を行なっていたのである。

\section{1 - 5. 第二独立期}

1952 年、群島政府の廃止に伴い退職、仲座久雄建築設計事務所を 真和志村栄町で再開した。

独立の年、地元新聞に「建築と災害」の題で論考を 5 回に亘って 連載している ${ }^{21)}$ 。の中で、沖縄では漏電による火災が 1949 年以 降増加していること、戦後の過密住宅地が延焼を拡大していること を危惧している注 29$)$ 。非木造建築を推し進める背景には、台風被害 に限らず火災被害も深刻な状況であったことが分かる。

第二独立期初期の代表的な作品に、1953 年竣工の煉瓦造、木造赤 瓦亘き屋根の琉球政府立博物館がある。博物館建設は、博物館職員 らが連日煉瓦を求めて「10 ヶ所ばかりの煉瓦工場をかけ迴って集め た」とあるように、資材不足や資金面で中断されるなど建設は難航 したが、待望された施設であった注30)。同年竣工の沖縄会館 (Photo 5）も煉瓦造であるが、2 階建て、屋根は RC 造スラブであり、 $\mathrm{RC}$ 造の外階段とテラスが、組積造の量感ある本体と対象的で軽快であ る。このように、第二独立期初期の 1953 年までは煉瓦造を手がけ たが、1954 年以降は RC 造が主体となっている。

1954 年竣工の子供博物館（Photo 6） は RC 造 2 階建て、2 階平 面が 1 階平面より大きく、四方に張り出した外観をなし、背面の一 部にピロティを有している。沖縄で最初のピロティ建築とされてい るのは、本土の大手設計事務所である松田平田設計事務所が設計し た 1952 年竣工の行政府ビルであるが注 31)、仲座の設計物には 1954 年以降からピロティが現れている注 ${ }^{32)}$ 。琉球大学図書館 (Photo 7) は RC 造 5 階建て、外壁がタイル仕上げと比較的豪華な造りであり、 ガラスのファサードと整列した正方形の小窓がアクセントになった モダンなデザインでまとめられている。那羁市納骨堂 (Photo 8) は $\mathrm{Y}$ 字型平面と連続するヴォールトの屋根が特徵であり、ヴォールト は沖縄の伝統的な墓形式である亀甲墓の円弧状の庇から形態を引用 したようであるが注 33)、独創性のある造形的なデザインといえる。

第二独立期の住宅設計については、初期である 1953 年以前は 10 件中 5 件が木造、 4 件が CB 造である。対して、1954 年以降は木造 の割合が減少し、1955 年以降は $\mathrm{RC}$ 造が主体となっている (3 章)。

群島政府期に引き続き、第二独立期初期の公共建築には組積造を 採用していたが、1954 年以降は RC 造を用い、加えてピロティや片 持ちスラブ、自由な造形など、 $\mathrm{RC}$ 造の特性を活かした構成へデザ インが変化している。このような、柔軟な設計手法の転換は、各建 材への知識や設計技術を保持していたこと、建築への旺盛な探究心 が現われているといえよう。

\section{2. 沖縄建築士会の活動}

戦後沖縄では、米軍工事の影響で民間工事においても設計・施工 の分離発注が一般化しており、設計業務を行う建築士はコンクリー 卜住宅普及の担い手となった。

仲座は、1955 年 12 月に設立された沖縄建築士会（以下、士会） 注34) の初代会長に就任し、逝去する 1962 年までの 7 年間務めた。在 任中は、指導的な立場からコンクリート住宅普及活動に多数取り組 んだ。 


\section{2-1. 住宅座談会}

1956 年 8 月、「浜口ミホ氏を囲む座談会」を開催した。文部省派 遣教授団として来島した浜口ミホ注 ${ }^{35)}$ は、農村地域の住宅を視察し た感想として、便所や浴室が衛生的でない、各部屋が暗い、と指摘 している。仲座は、住宅の復興政策が不十分な現状を解説し、日本 の住宅政策について浜口と情報交換を行った。会の記事によると、 沖縄では耐火構造の融資返済期間が 20 年であるのに対し、日本は 木造が 20 年、耐火構造は 35 年。不動産取得税も沖縄では建設後直 ちに課税されるのに対し、日本では 3 年間非課税とある注 36$)$ 。仲座 は土会会長として、住宅に関する金融政策の是正要請を繰り返し行 っており、この頃には強い意識を持っていたことが現れている。

1960 年 6 月、士会役員 19 名が参加し「住宅座談会」を開催した。 会では、前年 9 月に琉球政府注 ${ }^{37)}$ の企画統計局と工務交通局が共同 で行った住宅調查の報告資料をもとに討議している注 ${ }^{38)}$ ここの調查 結果については、1月に新聞掲載されており、「四万二千所帯が住宅 難 本土の五年前と同じ状態 耐火住宅はわずかに七\%」の見出しで、 深刻な状況が公開された ${ }^{23)}$ 。会においても、融資制度と不動産税の 緩和の必要性について議論が交わされている。また、コンクリート ブロックについて、輸入頼みの木材に比べて地元材が利用できると し、工場生産による質と価格の安定にも期待が寄せられている。

このように、士会では住宅品質改善及び融資制度と不動産税の緩 和の必要性について頻繁に議論していたことが分かる。これらは、 1958 年に琉球政府行政主席宛に二度に亘り「住宅に対する不動産税 の基礎控除の引上げについて」陳情注 39 )を行うなど、実行に移され ており、仲座の活動が大きく貢献したものとして評価できる。

\section{2-1-1. 米琉技術者座談会}

1959 年 10 月、在沖米人技術者と士会役員らによる「米琉技術者 座談会」を開催した。これは、9 月に宮古島で 7 割の住宅を損壊す る甚大な被害をもたらした宮古島台風（サラ）注 40)を受け、琉球政 府副主席より依頼された、復旧策と耐台風住宅を検討することを目 的に、技術開発委員会のオーマー・E・ローラー注 41$)$ の呼びかけによ り開催された。会の初めに、米技術者から耐台風農家住宅について 提案が求められると、士会側総意で「コンクリート、ブロック造り 以外にはない」と返答している。これを受け、農村地域でコンクリ 一ト住宅を普及する為の策が話しあわれ、低所得者も利用可能な、 コンクリート住宅に有利な融資制度を整えるよう要望が出された。 さらに「沖縄では公的援助がなく、復金注 ${ }^{42}$ だけだ、技術開発委員 会は高等弁務官の諮問機関と聞いているので、ブース弁務官に対し 大巾な経済援助を要請して貴い度い」と琉球列島米国民政府(以下、 米国民政府）注 ${ }^{43)}$ 一働きかけるよう米技術者に依頼した注 ${ }^{44)}$ 。

農村地域に及ぶ沖縄全域でのコンクリート住宅普及の必要性は、 在沖米人技術者と地元技術者の総意であったことが分かる。

\section{2-2． 農村住宅設計コンクール}

1960 年 1 月、「農村住宅設計コンクール」について地元新聞に公 募が掲載されている ${ }^{24)}$ 。主旨には、「去年の相つぐ台風で、大きな被 害を被った地方農村住宅の恒久的な対策をうちたてよう」とあり、 構造及び規模について「鉄筋コンクリート造、コンクリートブロッ ク造、煉瓦造、石造、屋根は鉄筋コンクリートスラブ、十五坪の平
屋建とし、一坪内外の増減は差支えない。家族構成は五人ていど」 と定めている。4 月に審査が行われ、37 作品の応募から 1 等に 20 代前半の若手建築士の案が当選、全 11 作品が入選した注 45$)$ 。 1 等案 は、外部と内部の両側から直接利用できる便所の配置、農作業帰り に家族と一緒に囲める土間と板間をまたいだ食卓の提案など、農家 の生活に即し、独創性も兼ねた作品である。また、全入選作品の構 造は、 $\mathrm{RC}$ 造もしくは $\mathrm{CB}$ 造である。入選作品は新聞に「新しい農家 の住宅設計」の題で、図面と解説付きで 11 回連載 ${ }^{25)}$ され広く一般 へ公開された。

農村住宅設計コンクールは、若手建築士を育成すると同時に、入 選作品を新聞に掲載することで、新しい農村住宅像を周知する試み であったといえる。

\section{2-3． 農村住宅小冊子の発行}

1960 年 5 月、米国民政府は『琉球における経済的農村モダン住宅 耐風、白蟻防除に最適』の題で小冊子（以下、農村住宅小冊子）を 刊行した ${ }^{26)}$ 。1959 年末に相次いだ台風（サラ、シャーロット、エ マ）注 ${ }^{46)}$ の被害を受け、琉球政府行政主席からの命により、技術開 発委員会のオーマー・E・ローラーが作成した報告書をもとに発行 したとある。編集には、士会会長として仲座も関与しており、米琉 技術者座談会からの一連の活動であることが分かる。

巻頭には、実例として仲座が 1954 年に設計したモデル農家住宅 （3 章）が掲載されている。また、本文では「木造家屋は、最初の 建設費は幾分安いが、寿命が短い上に、毎年修理を要するので、総 体的に考えると、コンクリート家屋の方が経済的である」と主張し ている。コンクリート住宅の湿気対策については、南面に建築し、 全開できる窓、深い庇、床下換気口を設置、内部は木造とすること が示されている。白蟻対策については、白蟻の特性、地面処理法、 木材処理法、駆除薬剤の配合が具体的に示され、直ちに応用できる 内容になっている。結論では「琉球における農村住宅は、壁をコン クリート、ブロックで造り、屋根はコンクリート、スラブとし、床 等の内部構造は防腐処理した木材を使用するのが、最良の建築方法 だと信ずる」と提言し、コンクリート住宅を強く推奨している。巻 末では、米国民政府民政官と琉球政府行政主席への提案事項を 9 項 目示しており、その中で、コンクリート住宅に有利な融資制度、税 制度の是正も求めており、一貫した要請がなされている。

1959 年末の台風被害を受け、琉球政府の依頼により米側沖縄側の 建築技術者が動員され、考案されたコンクリート住宅が示されるな ど、普及活動の勢いは加速したことが窥える。

\section{3. 住宅設計}

仲座が戦後設計した個人住宅で、図面もしくは間取り図、写真に よって確認できるもの 57 件を、設計年順に一覧表（Table 2）にま とめた注 ${ }^{47)}$ 。時系列及び構造種別ごとに住宅品質改善に係る実践内 容を以下に考察する。

\section{3-1。 木造住宅}

仲座は非木造住宅を奨励する一方で、木造住宅も多数手がけた。 1953 年以降、割合は減少するが 1960 年まで設計が確認できる。こ れらの木造住宅は、比較的簡素な造りであることを鑑み、建設費を 
安く抑える為に採用し続けたと考えられる。

1949 年設計の事務所兼自邸の仲座久雄建築設計事務所 (Photo 9) は、「屋根は片流れで防水層の上にセメントモルタル仕上」、螺旋階 段を設け、手寸りを天井から吊るなど「新しい構造システムを用い た木造建築構造に対する試作」と述へ、実験的な住宅であった注 48 。

沖縄の伝統的な木造住宅は、風通しの良い南面する部屋には仏間 があり、仏壇や床の間で隔てられた北面する部屋は裏座とよばれ、 通風や採光が悪く不衛生な場合が多かった。しかし、慣習を尊重す る農村地域においては、この様式を依然として採用することがあり、 こうした現状を批判する内容を含んだ「建築構造形式の改革」とい う手記を 1949 年に残している ${ }^{27)}$ 。

仲座は 1955 年以降、木造住宅の水回り部分に CB 造を用いたも のを設計している。高温多湿な沖縄では、構造材の腐食を避ける為、 水回り部分は別棟と寸ることが一般的であったが不便である。台所、 浴室、便所などの水回り部分に $\mathrm{CB}$ 造を用い、耐久性や衛生面に対 処しつつ利便性を向上する合理的な手法を取っていた。

\section{3-2. 石造・煉瓦造住宅}

石造・煉瓦造による住宅は、第一独立期に重複する 1949 年から 1950 年にのみ設計している。仲座は 1949 年末に地元文芸雑誌に 「風と火に耐える家にわれは住みたい」28) という題の手記を掲載し ており、「赤い煉瓦の家、美しき穴明きの小石積、苔生えた石積夕の 優雅赤瓦の屋根、白き漆喰、準耐火造の家、耐風的な家、耐久的な 構造、これは一建築家の夢であろうか」と記し、伝統的な地場材料 を用いた「風と火に耐える家」を構想していた。

同雑誌に「石の家」(Photo 10)、「煉瓦の家」についても連載して いる $\left.{ }^{29)} 30\right)$ 。いずれも平面図と外観透視図を掲載、設計経緯や工事費 などを詳細に述べている。両住宅とも、1949 年のグロリア台風によ る被害を受けての設計依頼であり、耐台風として組積造を採用、シ ンプルな平面構成で、南北両面に全開放できる大きな開口部、南面 に雨端（アマハジ）と呼ばれる伝統的民家にある軒下空間を設け、 通風と採光を確保した気候風土に配慮した設計がなされている。屋 根は同年設計の仲座久雄建築設計事務所と同様の木造であるが仕様 は「片流れ野地板は七分板を張ってルーフィングを二層張りセメン トモルタルを一吋厚さ塗ってルーフィングが風に吹飛ばされない」 という工夫が凝らされている。また、工事費の内訳も示されており、 木造より安価であると主張している注 ${ }^{49)}$ 。

1950 年設計の宮城氏住宅は琉球石灰岩の切石による栗石造で、屋 根は水勾配を施した RC 造陸屋根である (Fig. 1)。南北の通風を確 保し、庇とアマ八ジが設けられている。図面を一見すると、切石が コンクリートブロックの様に見え CB 造と見間違えるほど、同一の 構成となっており、過渡期の組積造住宅と位置付けられる。

このようにして、住宅の非木造化はコンクリート住宅一辺倒で行 われたのではなく、石造、煉瓦造の検討を経て遂行された。また、 このような組積造住宅、特に石造については、管見の限り仲座独自 の働きであり、コンクリート住宅普及以前の僅かな期間にのみ見ら れるこの時期特有の建築である。

\section{3-3. CB 造住宅}

沖縄で初めて CB 造住宅が建設されたのは 1950 年であり、沖縄
Table 2 Works list of private house

\begin{tabular}{|c|c|c|c|}
\hline Year & Title & Story & Structure \\
\hline \multirow{3}{*}{1949} & Hisao Nakaza office（仲座久雄建築設計事務所） & 2 & $\mathrm{~W}$ \\
\hline & Stone house（石の家） & 1 & Stone \\
\hline & Brick house（煉瓦の家） & 1 & Brick \\
\hline \multirow{2}{*}{1950} & Miyagi house（宮城氏住宅） & 1 & Stone \\
\hline & Okuhara house（奥原氏住宅） & 1 & $\mathrm{~W}$ \\
\hline \multirow{7}{*}{1952} & Ikemiya house（池宮氏住宅） & 2 & $\mathrm{CB}$ \\
\hline & Gibo house（儀保氏住宅） & 2 & $\mathrm{CB}$ \\
\hline & Tanahara house（棚原氏住宅） & 1 & W \\
\hline & Higashionna house（東恩納氏住宅） & 1 & $\mathrm{CB}$ \\
\hline & Kuniyoshi house（國吉氏住宅） & 2 & $\mathrm{~W}$ \\
\hline & Nakahara house（中原氏住宅） & 2 & $\mathrm{~W}$ \\
\hline & Koki house（幸喜氏住宅） & 2 & $\mathrm{~W}$ \\
\hline \multirow{3}{*}{1953} & Nakajyun office-cum-house（仲順氏事務所兼住宅） & 2 & $\mathrm{CB}$ \\
\hline & Gima shop-cum-house（儀間氏商店兼住宅） & 2 & $\mathrm{~W}$ \\
\hline & Jyuko Toma house（当間重剛氏住宅） & 2 & $\mathrm{RC} *$ \\
\hline \multirow{5}{*}{1954} & Farmer house model（モデル農家住宅） & 1 & $\mathrm{CB}$ \\
\hline & Arai house（新井氏住宅） & 1 & $\mathrm{CB}$ \\
\hline & Goya shop-cum-house（呉屋氏店舗兼住宅） & 1 & $\mathrm{~W}$ \\
\hline & Taira house（平良氏住宅） & 1 & $\mathrm{CB}$ \\
\hline & Hisao Nakaza office（仲座久雄建築設計事務所） & $\mathrm{B} 1+3$ & $\mathrm{RC} *$ \\
\hline \multirow{8}{*}{1955} & Inafuku shop-cum-house（稲福氏店舗兼住宅） & 2 & $\mathrm{RC} *$ \\
\hline & Moromizato house（諸見里氏住宅） & 1 & $\mathrm{CB}$ \\
\hline & Higa house（比嘉氏住宅） & 1 & $\mathrm{CB}$ \\
\hline & Yamauchi house（山内氏住宅） & 1 & $\mathrm{~W}+\mathrm{CB}$ \\
\hline & Tanahara house（棚原氏住宅） & 1 & $\mathrm{~W}$ \\
\hline & Nashiro house（名城氏住宅） & 2 & $\mathrm{RC} *$ \\
\hline & Kubota house（久保田氏住宅） & 1 & $\mathrm{RC} *$ \\
\hline & Nakai shop-cum-house（中井氏店舗兼住宅） & 2 & $\mathrm{RC} *$ \\
\hline \multirow{6}{*}{1956} & Naka house（名嘉氏住宅） & 1 & $\mathrm{RC}$ \\
\hline & Kinjo house（金城氏住宅） & 1 & $\mathrm{~W}$ \\
\hline & Nakaima house（中今氏住宅） & 2 & $\mathrm{RC} *$ \\
\hline & Higa house（比嘉氏住宅） & 1 & $\mathrm{RC} *$ \\
\hline & Enomoto house（榎本氏住宅） & 1 & $\mathrm{~W}$ \\
\hline & Inafuku house（稲福氏住宅） & 1 & $\mathrm{RC} *$ \\
\hline \multirow{8}{*}{1957} & Matsushima house（松島氏住宅） & 2 & $\mathrm{RC} *$ \\
\hline & Asato house（安里氏住宅） & 1 & $\mathrm{RC}$ \\
\hline & Kokuba house（國場氏住宅） & 1 & $\mathrm{~W}+\mathrm{CB}$ \\
\hline & Nagata house（長田氏住宅） & 2 & $\mathrm{RC} *$ \\
\hline & Kyoda house（許田氏住宅） & 1 & $\mathrm{~W}$ \\
\hline & Nakachi house（仲地氏住宅） & 2 & $\mathrm{~W}+\mathrm{CB}$ \\
\hline & Oyadomari house（親泊氏住宅） & 2 & $\mathrm{RC}$ \\
\hline & Yamashiro house（山城氏住宅） & 1 & $\mathrm{RC}$ \\
\hline \multirow{4}{*}{1958} & Arakaki house（新垣氏住宅） & 1 & $\mathrm{CB}$ \\
\hline & Nadoyama house（名渡山氏住宅） & 1 & $\mathrm{RC} *$ \\
\hline & Yogi house（與儀氏住宅） & 2 & $\mathrm{RC} *$ \\
\hline & Hokama shop-cum-house（外間氏店舗兼住宅） & 2 & $\mathrm{RC} *$ \\
\hline \multirow{2}{*}{1959} & Akamine house（阿賀嶺氏住宅） & 3 & $\mathrm{RC} *$ \\
\hline & Soken house（祖堅氏住宅） & 2 & $\mathrm{RC} *$ \\
\hline \multirow{6}{*}{1960} & Takara house（高良氏住宅） & 1 & $\mathrm{~W}$ \\
\hline & Kiba house（木場氏住宅） & 2 & $\mathrm{RC} *$ \\
\hline & Kubota house（窪田氏住宅） & 1 & $\mathrm{RC} *$ \\
\hline & Hanashiro house（花城氏住宅） & 3 & $\mathrm{RC} *$ \\
\hline & Kinjo house（金城氏住宅） & 1 & $\mathrm{~W}+\mathrm{CB}$ \\
\hline & Oyadomari house（親泊氏住宅） & 1 & $\mathrm{RC}$ \\
\hline \multirow{2}{*}{1961} & Kuba house（久場氏住宅） & 2 & $\mathrm{RC} *$ \\
\hline & Arakaki house（新垣氏住宅） & 2 & $\mathrm{RC}$ \\
\hline 1962 & Uehara house（上原氏住宅） & 2 & $\mathrm{RC} *$ \\
\hline
\end{tabular}

$\mathrm{W}:$ Wooden structure $\mathrm{CB}:$ Concrete block wall structure $\mathrm{RC}$ : Reinforced concrete frame structure $\mathrm{RC} *: \mathrm{RC}$ with screen blocks $\mathrm{W}+\mathrm{CB}$ : Wooden structure with $\mathrm{CB}$ used partially 
住宅公社が米軍人軍属向けに設計、約 2 年間で本島 6 地域に 308 棟 建設した 注 ${ }^{50)}$ 。当時、群島政府の建築課長であった仲座は、沖縄住 宅公社の理事会役員を務めており、CB 造住宅建設技術に直接触れ ることのできる立場にあった。仲座が CB 造住宅を設計し始めたの は 1952 年からであり、地元住民向けとしては最初期のものとなる。

当時の公社住宅は洋式生活様式で、土足生活に合わせて土間スラ ブに直接床を仕上げていたが、高温多湿な沖縄では結露し不衛生に なることが多い。一方、仲座の CB 造住宅の床は地盤面より高く、 $\mathrm{RC}$ 造基礎の上に木造床組で構成し、畳を設ける場合もあるなど在 来の生活様式に即している。

空には庇、特に大きな掃出し空にはアマハジを配し、開口部一杯 解放できるよう、ガラス障子や雨戸を収納する戸袋が設けられてい るものが多い (Fig. 2)。更に、不在時でも常時開放が可能な欄間空、 床下や天井裏には通気口を用いている場合も多く、通風に配慮して いる。仲座が設計した住宅には一貫して密の上部に庇が付いている が、元事務所所員によると「庇のない空はありえない」と徹底した 拘りがあったという注 51)。突発的な降雨が多い気候に対して、庇は 不可欠と考えていたのである。屋根は全て RC 造であり、水勾配を 確保した陸屋根、あるいは緩い勾配の切妻屋根である。

このような、 $\mathrm{CB}$ 造導入当初からの木造床上げ、日射遮蔽と通風 の確保、常時換気など、米人用住宅を単純応用しない気候風土に配 慮した設計手法を用いていたことは特筆されるべき点といえよう。

\section{3-3-1． モデル農家住宅}

1954 年設計のモデル農家住宅 (Photo 12) は、約 1 ケ月間 (1954 年 5 月 25 日から 6 月 27 日) に亘り一般公開され、来場者数は 2,000 人以上、琉球政府行政主席や米国民政府民政副長官らも来場し 32333、 関連記事が地元新聞に複数回掲載されるなど、大きな反響を得たこ とが窥える。 5 月 11 日の新聞記事 ${ }^{34)}$ に、設計経緯が掲載されてい る。それによると、仲座は米国民政府民政副長官デビッド・A・D ・ オグデンからの依頼に応じてモデル農家住宅案を提出したが、設計 料の受け取りを断り、副長官に農村住宅の現状を説明、品質改善に は復金融資期限（8 年）を延長する必要があると説き、賛同を得た とある。記事には、住宅の特徴も詳細に記されている。CB 造の採用 は、ブロックの積み上げを地域住民の共同作業で行い、大工手間を 減らす意図がある。部屋の間仕切りの欄間には無双空を設け、部屋 間の通風を確保している。屋根は $\mathrm{RC}$ 造スラブに水勾配をとり、雨 水はタンクに貯水される。また、屋上に張った水を天日に当てて温 める「熱湯装置」を設け、入浴に利用できるという。工事費は、坪 単価約 9,300 円 ${ }^{35)}$ としているが、当時の在来赤瓦莫き木造住宅の工 事費と比較しても安価である ${ }^{\text {注 }}$ 52)。5 月 12 日には、新聞社説 ${ }^{36)}$ で 「農家住宅と復金融資」の題で扱われ、モデル農家住宅を高く評価 すると同時に、融資制度の緩和が要望されている。

他住宅と同様、気候風土への配慮が見られるのに加え、コンクリ 一ト仕上げの土間のアマハジと台所、屋外から直接出入りできる浴 室など、農家の生活に即した設計がなされている。更に、雨水槽を 設置、「熱湯装置」を開発するなど斬新な試みも見られる。遺族への 聞き取りにより、モデル農家住宅は自費建設であったことが判明し ており、仲座の農家住宅改善にかける強い意気込从が窥える。

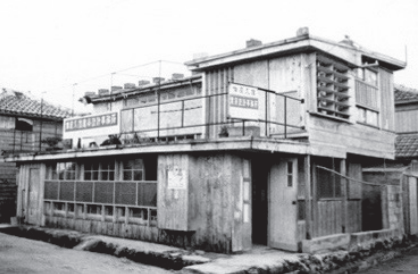

Photo 9 Hisao Nakaza office (1949)

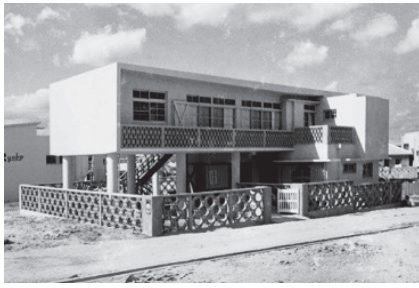

Photo 11 Jyuko Toma house (1953)

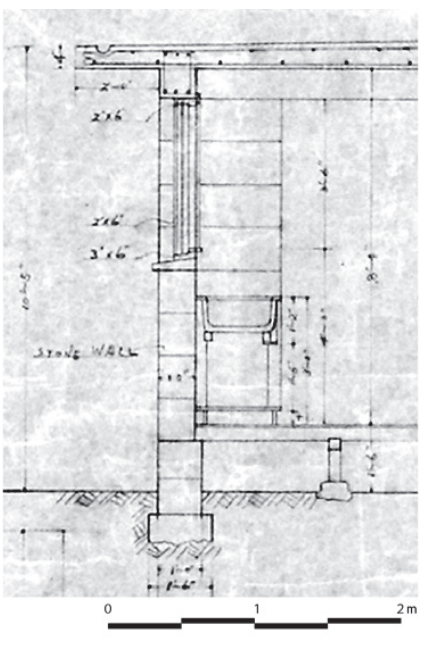

Fig. 1 Miyagi house (1950)

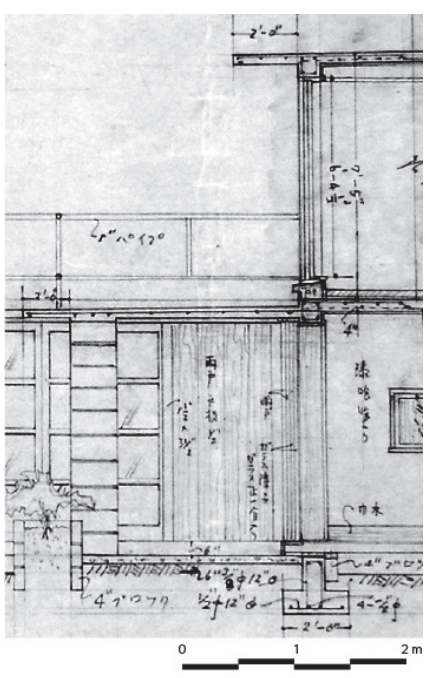

Fig. 2 Ikemiya house (1952)

\section{3-4. R C 造住宅}

$\mathrm{RC}$ 造住宅は 1953 年以降から設計され始めた。当時、那覇市長を 務めていた当間重剛の住宅 (Photo 11) は、RC 造 2 階建て、1 階に 円柱が並ぶピロティを有し、スクリーンブロック（以下、花ブロッ ク）注 53)を手すりや塀に用いた外観が特徴である。婦人が住宅で開 
講する「たしなみ」教室について掲載した記事 ${ }^{37}$ によると、建設費 は 100 余万円と住宅としては高額であり、施工は地元大手建設会社 で行政府ビルの施工も手がけた國場組である。その為、住宅として は比較的早い時期に RC 造を採用できたと推察できる。

1956 年以降は、RC 造住宅が主流となっている。増加の要因は、 建設に必要な材料や技術の普及の他、壁式である CB 造に比べて開 口部を広く確保できること、加えて将来の増改築が容易な点だと考 えられる。同時に、花ブロックが頻繁に用いられるようになってお り、その需要に応じるものとも推察できる。

$\mathrm{RC}$ 造住宅も $\mathrm{CB}$ 造住宅と同様に庇、アマハジ、欄間空、木造床上 げ、天井仕上げ、床下と天井裏の通気口の設置など、気候風土に配 慮した設計がなされている。屋根は多くの場合 $\mathrm{RC}$ 造の陸屋根であ るが、1955 年設計の久保田氏住宅 (Photo 14) は寄棟形状の RC 造 スラブ屋根の上に赤瓦漆喰仕上げを施しており、伝統家屋の意匠を 融合した設計である注 ${ }^{54)}$

\section{3-5． 花ブロック}

花ブロックを用いた代表作は、1954 年設計の事務所兼自邸である 仲座久雄建築設計事務所 (Photo 13) である。地下 1 階地上 3 階建 て、花ブロックを四面に配した個性的な外観が特徴である。花ブロ ック部分は内側にガラス建具を設けたダブルスキンで構成されてお り、日射遮蔽しつつ、通風を確保できる (Fig. 3)。花ブロック製造 工場である旭ブロックの 1959 年版カタログ表紙には仲座久雄建築 設計事務所の外観写真が用いられている注 55)。巻頭に、「仲座久雄先 生御設計最高の品質最大の生産」とあり、リストには仲座考案とさ れる花ブロック型が 7 種類掲載されている。仲座久雄建築設計事務 所は行政府ビルの真向かいという那覇中心地に立地し、個性的な外 観が広告塔の役割を担っていたと想像できる。花ブロックに対する 仲座の考えを確認できる資料として、1953 年設計のカネコ書房を紹 介寸る記事がある ${ }^{38)}$ 。型は沖縄の伝統織物のかすり模様をヒントに 図案化。沖縄の気候では、腐食しやすい鉄類に比べ、花ブロック（原 文は、プレカストコンクリート）は適した材であるとしている。

伝統工芸を近代建築の意匠に変換し外観を彩り、日射を遮蔽する と同時に通風を確保でき、耐久性が高い花ブロックの沖縄の亜熱帯 気候での有用性と意匠性を見出していたことが分かる。

\section{まとめ}

以上のように、仲座久雄は戦後沖縄のコンクリート住宅普及活動 に技術面 (設計)、広報面（執筆などによる啓蒙）、経済面（金融政 策への要請）、教育面（士会での建築士育成）の多方面において尽力

し、普及黎明期の主要な基盤を形成していった。

本研究は、戦後沖縄建築の成立過程は、占領下における先進技術 の一方的な享受のみでなく、地元建築家による地域の事情に根ざし た取り組みも相乗して近代化を辿った経緯を明らかにした。

\section{謝辞}

仲座久雄ご子息の仲座嚴氏には資料提供や聞き取りに協力頂き、

助言を賜りました。記して謝意を表します。 本研究は科学研究助成金（基盤研究 C、課題番号：16K06687）を 受けた。

\section{参考文献}

1) Ogura, N.: Characteristics of design methods on the distribution of RC building in the postwar Okinawa -with a focus on the planning of post office building-, AIJ Kyushu Chapter Architectural Research Meeting, vol. 41, pp. 425-428, 2002. 3 (in Japanese)

小倉暢之: 戦後沖縄のコンクリート建築普及における設計技術の特質 - 郵 便局舎の平面について一、日本建築学会九州支部研究報告、第 41 号、pp. 425-428、2002. 3

2) Ogura, N.: Characteristics of design methods on the distribution of RC building in the postwar Okinawa -Part 2: with a focus on the architectural background and planning methods-, AIJ Kyushu Chapter Architectural Research Meeting, vol. 42, pp. 621-624, 2003. 3 (in Japanese)

小倉暢之 : 戦後沖縄のコンクリート建築普及における設計技術の特質 -そ の 2 設計の背景と平面計画-、日本建築学会九州支部研究報告、第 42 号、 pp. 621-624、2003. 3

3) Ogura, N.: Formation process on the acts of the quality control of concrete blocks in postwar Okinawa, AIJ Kyushu Chapter Architectural Research Meeting, vol. 43, pp. 593-596, 2004. 3 (in Japanese)

小倉暢之: 戦後沖縄におけるコンクリートブロック品質保全法の成立過程、 日本建築学会九州支部研究報告、第 43 号、pp. 593-596、2004. 3

4) Kinjo, H. and Ogura, N.: The plan and supply of the standard prefabricated house in Okinawa postwar reconstruction, Journal of architecture and planning (Transactions of AIJ), vol. 83 no. 744, pp. 307-314, 2018. 2 (in Japanese)

金城春野、小倉暢之 : 沖縄戦後復興における規格住宅の計画と供給につい て、日本建築学会計画系論文集、第 83 巻第 744 号、pp.307-314、2018.2

5) Goya, S. and Ogura, N.: Study on the evolution of concrete house in Okinawa, AIJ Kyushu Chapter Architectural Research Meeting, vol. 44, pp. 761-764, 2005. 3 (in Japanese)

呉屋さゆり、小倉暢之 : 沖縄県におけるコンクリート住宅の展開に関する 研究、日本建築学会九州支部研究報告、第 44 号、pp. 761-764、2005. 3

6) Nakajima, C. Ikeda, T. and Ogura, N.: A study on the progress of the U.S. military housing project and planning management technology by the Okinawa housing corporation in postwar Okinawa, Journal of architecture and planning (Transactions of AIJ), no. 566, pp. 105-111, 2003. 4 (in Japanese)

中島親寛、池田孝之、小倉暢之 : 戦後の沖縄における沖縄住宅公社による 米軍住宅建設プロセスと計画管理技術に関する研究、日本建築学会計画系 論文集、第 566 号、pp. 105-111、2003. 4

7) Okinawa prefectural museum: exhibition "Prewar · postwar cultural properties protection" - Through Hisao Nakaza's activity -, Okinawa prefectural museum, 2004. 2. 10 (in Japanese)

沖縄県立博物館 : 企画展「戦前・戦後の文化財保護」一仲座久雄の活動をと おして一、沖縄県立博物館、2004.2.10

8) Okinawa society of architects \& building engineers: Okinawa architects, the first issue, vol. 2 6, Return special issue, 1957. 12. 1, 1958. 12. 1, 1959. 10. 15, 1960. 11. 15, 1961. 11. 30, 1963. 12. 1, 1972. 7. 29 (in Japanese) 沖縄建築士会 : 沖縄建築士、創刊号、2 6 号、復帰記念特集号、1957. 12. 1、1958.12.1、1959.10.15、1960.11.15、1961.11. 30、1963.12.1、 1972. 7. 29

9) Okinawa society of architects \& building engineers: Okinawa architecture, vol. 23 (Nakaza special issue), vol. 36 (50th anniversary special issue), 1989. 12. 20, 2005. 9. 30(in Japanese) 沖縄建築士会 : 沖縄建築、23 号（仲座久雄特集）、36 号（50 周年特集）、 1989. 12. 20、2005. 9. 30

10) Okinawa prefecture department of civil engineering and construction: Doboku kenchiku gyôsei no 50 nen(Okinawa prefecture department of civil engineering and construction the 50th anniversary), Okinawa prefecture center of constructional technology, 1995. 12 (in Japanese) 沖縄県土木建築部技術管理室 : 土木建築行政の 50 年、財団法人沖縄県建 設技術センター、1995. 12

11) Okinawa prefectural museum: Okinawa prefectural museum the 50th anniversary, 1996. 12. 6 (in Japanese) 
沖縄県立博物館：沖縄県立博物館 50 年史、1996. 12.6

12) Kinjo, H. and Ogura, N.: Study on the early stage of the concrete house in Okinawa -Focused on the design of Hisao Nakaza-, Summaries of Technical Papers of Annual Meeting, Architectural Institute of Japan, History and Theory of Architecture, pp. 871-872, 2016. 8 (in Japanese) 金城春野、小倉暢之 : 沖縄の初期コンクリート住宅について - 仲座久雄の 設計手法に検する研究-、日本建築学会大会学術講演梗概集、建築歴史・意 匠、pp. 871-872、2016.8

13) Sawada, H., Kinjo, H. and Ogura, N.: Development of the house construction and design method postwar Okinawa -Study on the architectural activities of Hisao Nakaza Part 2-, AIJ Kyushu Chapter Architectural Research Meeting, vol. 56, pp. 621-624, 2017. 3 (in Japanese)

佐和田浩希、金城春野、小倉暢之 : 戦後沖縄の住宅構法及び設計手法の展 開について 仲座久雄の建築活動に関する研究 その 2、日本建築学会九州 支部研究報告、第 56 号、pp. 621-624、2017. 3

14) Okinawa shinbun: Gendai hyakunin wo kiru (73) -Nakaza Hisao- (100 people of today (73) -Hisao Nakaza-), Okinawa shinbun, 1951. 7.7 (in Japanese)

沖縄新聞：現代百人をキル(73)仲座久雄 地道で築き上ぐ特産規格住宅の 生みの親、沖縄新聞、1951.7.7

15) Okinawa times: Okinawa encyclopedia, last volume, Okinawa times, 1983. 5. 30 (in Japanese)

沖縄タイムス社 : 沖縄大百科事典、下巻、沖縄タイムス社、1983.5. 30

16) Hisao Nakaza: Ten ten suru sumai (Changed houses frequently), part 1 4, Ryukyu shimpo newspaper, 1952. 1. 9, 13, 16, 20 (in Japanese) 仲座久雄 : 轉々寸る住まい、1 4、琉球新報、1952. 1. 9、13、16、20

17) Uruma shinpô: Okinawa chûô byôin rakusei (The Okinawa central hospital was completed), Uruma shinpô, 1946.9.20 (in Japanese) うるま新報：沖縄中央病院落成、うるま新報、1946. 9. 20

18) Okinawa times: Okinawa no shôgen gekidô no 25 nen shi (Testimony of Okinawa. The turbulent 25 years), Okinawa times, 1971. 5 (in Japanese) 沖縄タイムス社 : 沖縄の証言激動の 25 年誌、沖縄タイムス社、1971. 5

19) Hisao Nakaza: 10 nen no jinbutsu (31). Gunmei de kikaku jyûtaku sekkei mokuô kôsha no haishi teishô (Person of ten years (31). Designed the standard prefabricated house by order of the military. Proposes the abolition of wooden school buildings), Okinawa times newspaper, No. 2288, 1956. 2. 3 (in Japanese)

仲座久雄 : 十年の人物(31) 軍命で規格住宅設計 木造校舎の廃止提唱、沖 縄タイムス新聞、1956.2.3

20) Rikoh tosho: Kenchiku kai (Architectre world), vol. 9-8, 1960. 8. 1 (in Japanese)

理工図書 : 建築界、第 9 巻第 8 号、1960.8.1

21) Hisao Nakaza: Kenchiku to saigai (Architecture and disaster), part 1 5, Ryukyu shimpo newspaper, 1952. 8. 25-29 (in Japanese) 仲座久雄 : 建築と災害、1 5、琉球新報、1952.8.25-29

22) Kitagawa, K.: A study on housing architect Miho Hamaguchi -The career and "dinning-kitchen" of the Japanese housing public corporation-, Summaries of Technical Papers of Annual Meeting, Architectural Institute of Japan, History and Theory of Architecture, pp. 97-98, 2000. 9 (in Japanes)

北川圭子 : 住宅建築家・浜口ミホについての考察 -経歴及び公団ダイニン グ・キッチンとの関わり -、日本建築学会大会学術講演梗概集、建築歴史・ 意匠、pp. 97-98、2000.9

23) Okinawa times: Jittai chôsa matomaru (Actual condition survey -To basics document of housing policy-), Okinawa times, 1960. 1. 24 (in Japanese)

沖縄タイムス: 実態調査まとまる 住宅政策の基礎資料に、沖縄タイムス、 1960. 1. 24

24) Okinawa times: Nôson jyûtaku konkûru (Farmer house competition), Okinawa times, 1960. 1. 13 (in Japanese)

沖縄タイムス、農村住宅設計コンクール、沖縄タイムス、1960.1.13

25) Okinawa times: Atarasî nôka no jyûtaku sekkei (New type of farmer house), part 1 11, Okinawa times, 1960. 5. 7, 9-18 (in Japanese) 沖縄タイムス、新しい農家の住宅設計、1～11、沖縄タイムス、1960.5.7,
9-18

26) United states civil administration of the Ryukyu islands (USCAR): Ryukyu ni okeru keizaiteki nôson modan jyûtaku (Farmer modern house in Ryukyu), USCAR, 1960. 5. 30 (in Japanese)

琉球列島米国民政府：琉球における経済的農村モダン住宅 耐風・白蟻防 除に最適、琉球列島米国民政府、1960.5. 30

27) Hisoa Nakaza: Kenchiku kôzô keishiki no kaikaku (Architectural style reform), Gekkan taimusu, 1949.10.18 仲座久雄 : 建築構造形式の改革、月刊タイムス、1949.10.18

28) Hisao Nakaza: Kaze to hi ni taeru ie ni ware wa sumitai (I want to live in the house resistant to wind and fire), Uruma shunjyû, the first issue, pp. 3-4, 1949. 1 (in Japanese)

仲座久雄 : 風と火に耐える家にわれは住みたい、うるま春秋、創刊号、pp. 3-4、1949. 1

29) Hisao Nakaza: Ishi no ie (Stone house), Uruma shunjyû, vol. 2-1, pp. 14, 1950. 2 (in Japanese) 仲座久雄 : 石の家、うるま春秋、第 2 巻 1 号、pp. 1-4、1950. 2

30) Hisao Nakaza: Renga no ie (Brick house), Uruma shunjyû, vol. 2-2, pp. 1-7, 1949. 12

仲座久雄 : 煉瓦の家、うるま春秋、第 2 巻 2 号、pp. 1-17、1949. 12

31) Hisao Nakaza: Chikujyô to kankô (Ruins of castle and tourism), Uruma shunjyû, vol. 2-3, pp. 16-21, 1950. 4 仲座久雄 : 築城と観光、うるま春秋、第 2 巻 3 号、pp. 16-21、1950.4

32) Okinawa times: Moderu nôka (Farmer house model), Okinawa times, 1954. 6. 27 (in Japanese) 沖縄タイムス：モデル農家、沖縄タイムス、1954.6.27

33) Ryukyu shimpo: Syuseki mo homeru moderu nôka (Chairman praised the farmer house model), 1954. 6. 29 (in Japanese) 琉球新報：主席もほめるモデル農家、琉球新報、1954.6.29

34) Ryukyu shimpo: Moderu nôka jyûtaku omemie (Farmer house model debut), Ryukyu shimpo, 1954. 5. 11 (in Japanese) 琉球新報：モデル農家住宅お目見え、琉球新報、1954.5.11

35) Okinawa times: Nôson moderu jyûtaku (Farmer house model), Okinawa times, 1954. 5. 26 (in Japanese) 沖縄タイムス：農村モデル住宅、沖縄タイムス、1954.5.26

36) Ryukyu shimpo: Sya setsu (Editorial column), Ryukyu simpo, 1954. 5. 12 (in Japanese)

琉球新報：社説、琉球新報、1954.5. 12

37) Ryukyu shimpo: Hanayome no tashinami ni (Finishing school), 1954. 10. 29 (in Japanese)

琉球新報：花嫁のたしなみに、琉球新報、1954.10.29

38) Ryukyu shimpo: Kindai Naha (Modern Naha), 1955. 5. 9 (in Japanese) 琉球新報：近代那覇、琉球新報、1955.5.9

注

注1）沖縄建築士会が創立 50 周年にまとめた、「沖縄建築の系譜」の第一世 代（1900、1910 年代生まれ）には、仲座久雄、大城龍太郎、ジョーゲ ン・シャーベック、大城重信、山里銀造、具志堅博の 6 人の建築家があ げられている。そのうち、大城龍太郎と大城重信は戦後に帰郷、シャー ベックは 1950 年代に来沖しており、終戦直後から活躍できた建築家は 少ない。参考文献 9 (36 号) 、pp. 65-71参照。

注2）参考文献 9 (36 号)、p. 70 参照。

注3） 1948 年に米軍工兵隊が CB 工場を建設。1950 年に米国は沖縄の恒久 的基地建設を発表、 $\mathrm{RC}$ 造による建設が活発化。参考文献 5 参照。

注4) 参考文献 8 (復帰記念特集号)、p. 49 参照。

注5） 2015 年中頃から 2018 年 2 月に亘って、那覇市にある仲座久雄のご子 息宅にてインタビューと資料整理に協力頂き、資料の画像データを預 かった (筆者保管)。なお、参考文献にある手記および新聞記事で、こ れに含まれていたものは14)、16)、19)、20)、21)、27)、28)、29)、30)、 31）、32）、33）、34）、35，36）、38)である。その全てについて現物を 確認し、特に、切抜き（一部抜粋など）で所蔵されていたものについて は、沖縄県立図書館および琉球大学付属図書館にて現物を調査した。

注6）建築士会機関紙は本土復帰以前に発行された号（参考文献 8)、仲座久 雄特集が組まれた号及び 50 周年記念号（参考文献 9）を参照した。

注7）文化財保護活動は、研究、執筆、修復工事、保存運動など、戦前から生 涯に亘って続けられた。この功績について、沖縄県立博物館は 2004 年 
に「企画展 戦前・戦後の文化財保護 仲座久雄の活動をとおして」を開 催している。参考文献 7 参照。

注8）「仲座久雄年譜」参考文献 7、pp. 10-11 参照。

注9）大阪期の活動を把握できる資料は乏しいが、遺族提供の図面の中には、 大阪期のものが数点あり、「日本基督住吉教會増築及改築設計図」(木造 2 階建て、1930 年頃)、「大阪同仁教會設計図仲座思案」（構造不明、 1930 年) の 2 件の教会建築の設計に関わっている。また、「某小学校鉄 筋コンクリート正門及墻壁設計図」（RC 造、1930 年）は仲座が製図を 担当（設計者には福井と記されている）している。

注10) 前掲注 8

注11）森政三（1895-1981）、北海道札幌市生まれ、東京美術学校建築学科卒 業。1929 年「国宝保存法」の制定にともない文部省技官となり、国宝、 重要文化財の調査、記録、修復を担当。参考文献 $15 、$ p. 680 参照。

注12) 前掲注 7

注13) 前掲注 8

注14）参考文献 16 （轉々寸る住まい 1）参照。

注15) 参考文献 4 参照。

注16) 前掲注 8

注17）コンセットとは、半円形の軽量鉄骨造、波型亜鉛鉄板莫きの米軍仮設兵 舎のことを指す。

注18）参考文献 17 参照。配置図は参考文献 7、p. 12 参照。

注19) 建設会社 AJ は、ロサンゼルスのアトキンソン (Atkins)とアトランタ のジョーンズ (Jones)の共同企業。当時、米軍工兵部隊から一括して工 事を請け負い、沖縄業者に下請けさせた。参考文献 18、p. 286 参照。

注20）前掲注 8 。松川で開設し、栄町に移転したことについては、遺族からの 聞き取りによる。

注21）「中城々公園鳥瞰図」を参照。参考文献 31、pp. 18-19 参照。

注22）沖縄群島政府（1950.11.4-1952.3.31）は、沖縄民政府に代わって設置さ れた、沖縄群島 (宮古、八重山を除く) における住民側の中央行政機関。 群島知事、及び群島議会議員は住民選挙で選ばれた。1952 年の琉球政 府の発足に伴い解消。

注23）参考文献 19、5 段目。参考文献 20、p. 21 参照。

注24）文部省標準設計を参考にした平面計画をしている為、標準型校舎と呼 ばれる。沖縄の標準型校舎には木造、 $\mathrm{RC}$ 造も存在したが、仲座が設計 したのは組積造の標準型校舎である。

注25）参考文献 8 (3 号)、pp. 6-8 に、「野石造」、「粟石造」、「煉瓦造」の標準 型校舎の写真が見出し付きで掲載されている。

注26) プレキャストコンクリートのラチス梁については参考文献 8 (復帰記念 特集号)、pp. 33-34 参照。施工の様子については参考文献 10、pp. 140141 参照。

注27）参考文献 19、5 段目参照。

注28） 1949 年 6 月デラ（最大風速 $49.5 \mathrm{~m} / \mathrm{s}$ ）、7 月グロリア（最大風速 46.4 $\mathrm{m} / \mathrm{s})$ 。参考文献 10、pp. 376-379 参照。

注29）参考文献 21 (第 5 回)、2-3 段目参照。

注30）参考文献 $11 、$ p. 43 参照。

注31）参考文献 10、pp. 141-142 参照。

注32） 1954 年竣工の当間重剛氏住宅（設計は 1953 年)、1955 年竣工の琉球 放送首里スタジオは 1 階にピロティがある。

注33）参考文献 8 (2 号) 、p. 32 に那覇市納骨堂の竣工写真、平面図と共に、 「沖縄古来の墓」として亀甲墓が 2 基並んだ写真が掲載されている。ヴ オールトの庇が相似しており、意図したデザインであることが窥える。

注34）沖縄建築士会（1955.12 設立）は、1952 年 12 月に建築基準法、1953 年 11 月に建築士法、1955 年 7 月に建設業法が制定されたことに伴い 設立された。参考文献 8 (4 号)、p. 76 参照。

注35) 浜口ミホ（1915-1988）は当時、戸板女子大学講師。住宅問題に取り組 んだ建築家であり、女性建築家第一号とされている。参考文献 22 参照。

注36) 参考文献 8 (創刊号)、pp. 32-34 参照。

注37）琉球政府（1952.4.1-1972.5.14）は沖縄群島政府に代わって設置された 住民側の統治機構。司法と行政の長 (行政主席) は米軍の任命であり（行 政主席は 1968 年に公選）米国民政府の監督下にあった。1972 年の日 本復帰により廃止。

注38) 参考文献 8（4号)、pp. 17-27 参照。

注39）市町村税法第 150 条「住宅の用に供する土地又は建物の不動産取得税 は土地にあっては二万円、建物にあっては五万円をその取得価格から 控除した金額を課税標準として課するものとする」の控除率引上げを 要望する陳情を行なった。参考文献 8 (2 号)、p. 61-62 参照。
注40） 1959 年 9 月サラ（最大風速 $53 \mathrm{~m} / \mathrm{s}$ ）別名第一宮古島台風。参考文献 10、pp. 376-379 参照。

注41）オーマー・E・ローラー (Omer ・ E ・ Roller $) 、$ 米国陸軍技術協会技術 開発委員会委員長、米国民政府経済開発部公益事業課長。

注42）琉球復興金融基金（復金）は 1950 年 4 月に琉球列島米国民政府布令 4 号により、戦後初の低利資金供給源として創設された。1959 年 12 月 に琉球開発金融公社 (開金)に業務を継承。これらの融資によって建設 された住宅は復金住宅、開金住宅と呼ばれている。

注43）琉球列島米国民政府（1950.12.15-1972.5.14）は、米国陸軍軍政府に代 わって設置された琉球政府の上部統治機構。初期の最高位は民政長官 であるが、アメリカ極東軍司令官を兼任していた為、在沖縄の民政副長 官が職務を行なっていた（1957 年から最高位は高等弁務官）。1972 年 の日本本土復帰により廃止。

注44）参考文献 8 (4 号)、pp. 40-41参照。米琉技術者座談会には、士会から 仲座を含めた 7 人、米側から 5 人と通訳 1 人が参加。

注45) 参考文献 8 (4 号)、pp. 28-39 参照。

注46）サラ（前掲注 40）、1959 年 10 月シャーロット（最大風速 $41.3 \mathrm{~m} / \mathrm{s}$ )、 11 月エマ (最大風速 $45.2 \mathrm{~m} / \mathrm{s}$ )。参考文献 10、pp. 376-379 参照。

注47）沖縄建築士会が仲座久雄特集を組んだ参考文献 9 (25 号)、pp. 24-25 の「仲座久雄の作品一覧」、遺族提供の仲座久雄資料の図面、及び手記 を参照、聞き取りにより補足した。

注48）参考文献 16 （轉々寸る住まい 4）参照。階段が螺旋階段であったこと は、遺族からの聞き取りによる。

注49）総工費 石の家：114,380 円、煉瓦の家：138,000 円（通貨は B 円）

注50) 参考文献 6 参照。

注51）元所員の根路銘安弘氏への聞き取り。根路銘氏は 1958 年から 1962 年 まで仲座久雄建築設計事務所に勤務。

注52）9,300 円は B 円であるので坪単価約 78 ドル（1 ドル＝120 B 円）とな るが、在来赤瓦莫き木造住宅の平均的な坪単価は 85 ドル(参考文献 26 、 p. 11）とされており、大分安い。住民の労務提供により工賃を抑えた 結果と思われる。

注53）沖縄では、スクリーンブロック（穴あきコンクリートブロック）を花ブ ロックと呼び、コンクリートブロック同様、米軍工事によってもたらさ れた。通風、目隠し、防犯等の機能があり、地元では公共建築や一般住 宅等で広く利用されている。

注54）久保田氏住宅の他、1959 年設計の祖堅氏住宅も寄棟形状の RC 造スラ ブ屋根に赤瓦漆喰仕上げを施している。

注55）旭ブロックは当時唯一の花ブロック工場であったとされている（当カ タログ記載)。原本は沖縄県立博物館・美術館所蔵。

\section{図版出典}

Table 1 参考文献 7 を参照し筆者作成

Table 2 筆者作成（注 47）

Fig. 1、2、3 遺族提供仲座久雄資料（原図は沖縄県立博物館所蔵）

Photo 1、4 History material office of Naha city: Shashin de tuzuru Naha sengo 50 nen 1945-1995 (Record with photographs of postwar 50 years. 1945-1995 Naha city), 1996. 3. 28, p. 100, 128 (in Japanese)

那覇市文化局歴史資料室 : 写真でつづる那覇戦後 50 年 1945-1995 那覇市、1996. 3. 28、p. 100、128

Photo 2、6、8、13 参考文献 7、p. 13、34、36、36

Photo 9、10、11 遺族提供仲座久雄資料（原図は沖縄県立博物館所蔵）

Photo 3 Okinawa prefectural board of education: Visual history of Okinawa Vol. 3 -History of the postwar development of school buildings and facilities-, 1999. 1. 20, p. 12 沖縄県教育委員会: 沖縄県史ビジュアル版 3 戦後 2 青空教室から の出発 戦後校舎のうつり変わり、1999.1.20、p. 12

Photo 5、7、14 参考文献 9 (36 号)、p. 41、23、21

Photo 12 参考文献 $26 、$ p. 4 


\title{
ARCHITECTS ACTIVITY ON HISAO NAKAZA \\ IN THE EARLY STAGE OF CONCRETE HOUSE POPULARIZATION IN OKINAWA
}

\author{
Haruno KINJO*1 and Nobuyuki OGURA*2 \\ ${ }^{* 1}$ Assist. Prof., Faculty of Engineering, University of the Ryukyus, M.Eng. \\ ${ }^{* 2}$ Prof., Faculty of Engineering, University of the Ryukyus, Ph.D.
}

Hisao Nakaza was one of a handful of architects who contributed to building activities in Okinawa before, during, and after the Second World War. He engaged in the post-war recovery construction in the forefront immediately after the war, and later served as the first president of the Okinawa Society of Architects \& Building Engineers (O.S.A.B.E.). Nakaza was a pioneer who represented Okinawan architectural society in the early post-war period.

This study defines the period before 1960 as the dawn of concrete house popularization in Okinawa and aims to clarify the aspects of the development of architecture in Okinawa during this period, examining the architectural activity of Hisao Nakaza, who played a leading role in laying the foundation for the spread of concrete buildings. Results obtained from each section are as follows:

1) Nakaza was engaged in the public construction work in Okinawa before the war. That experience correlated to his active involvement of public work of American Army immediately after the war and he obtained advanced technologies. He employed masonry construction methods, utilizing local materials from 1950 to 1953 when material procurement and factory equipment were incomplete for the Reinforced-Concrete (RC) building. After 1954, he made the most of the properties of RC building, which made free form possible and also designs were changed. He was also devoted to designing activities and writing activities for magazines and newspapers and enlightened people on the dissemination of non-wooden buildings.

2) During his tenure as the President of the O.S.A.B.E., Nakaza organized discussion meetings of engineers and competitions of farm house design. Discussion meetings promoted the common consciousness of the dissemination of concrete housing among the engineers. Competitions nurtured young architects and at the same time offered the opportunities to make people known a new image of farmers' housing. Furthermore, interactions between Japanese and American engineers staying in Okinawa through meeting led to the publication of booklets about rural houses. In addition, requirements for concrete housing suitable for the land and climate were presented. Furthermore, financing facilities and tax system revisions for the establishment of concrete buildings were requested to government.

3) In the development of housing design, starting from 1949, masonry construction was performed for two years. After stone building and brick building were examined, non-wooden building was fulfilled. Concrete block (CB) building was introduced to build plumbing water parts of wooden houses around 1955, which improves durability sanitation and handiness. CB building was frequently employed between 1952 and the beginning of 1955, which were designed by taking into consideration the climate features of the region from the beginning of the first introduction. The farmer house model of CB building was opened to the public and earned a great response. Finally, RC building entered the mainstream in 1956. At the same time, screen blocks were created and frequently utilized. The shape of screen blocks was contrived where both usability and exquisite design were found for the subtropical climate of Okinawa.

As stated above, Hisao Nakaza was dedicated to the activities of the dissemination of concrete housing in diversified fields such as technical aspect (design), publicity (writing to enlighten people) finance (request for the support of financial policies) and education (cultivate architect at O.S.A.B.E).

This study examined the process of Okinawan architecture after the war and revealed that the history of modernization was based on not only the unilateral receiving of advanced technology under military occupation but also the initiative struggle of the local architect, Nakaza, with roots in the region of Okinawa. 